STRUCTURAL CHEMISTRY (ISSN: 1040-0400) 26(5-6): 1377-1387 (2015) doi:10.1007/s11224-015-0674-9

\title{
Structural characterization of dinuclear gold(I) diphosphine complexes with anion-triggered luminescence
}

Péter Baranyai, ${ }^{[\mathrm{a}]}$ Gábor Marsi, ${ }^{[\mathrm{a}]}$ Andrea Hamza, ${ }^{[\mathrm{bb}}$ Csaba Jobbágy ${ }^{[\mathrm{a}]}$ and Andrea Deák ${ }^{*[a]}$

Dedicated to Professor Magdolna Hargittai on the occasion of her 70th birthday.

\section{Acknowledgements}

The authors gratefully acknowledge the support by MTA (Hungarian Academy of Sciences) through the Lendület Programme (LP2012-21/2012).

[a] P. Baranyai, G. Marsi, Cs. Jobbágy, A. Deák ${ }^{*}$ Hungarian Academy of Sciences, MTA TTK SZKI Lendület Supramolecular Chemistry Research Group 1117 Budapest, Magyar Tudósok körútja 2., Hungary E-mail: deak.andrea@ttk.mta.hu

[b] A. Hamza

Hungarian Academy of Sciences, MTA TTK SZKI

Theoretical Chemistry Research Group

1117 Budapest, Magyar Tudósok körútja 2., Hungary 


\section{Abstract}

Dinuclear and mononuclear gold(I) complexes containing the xantphos ligand (xantphos = 9,9'-dimethyl-4,5-bis(diphenylphosphino)-xanthene), $\left[\mathrm{Au}_{2}(\mathrm{xantphos})_{2}\right](\mathrm{X})_{2}$ with $\mathrm{X}=\mathrm{BF}_{4}(\mathbf{1})$, $\mathrm{PF}_{6}$ (2) and $\mathrm{SbF}_{6}(3$ and 4) and $\mathrm{Au}$ (xantphos)(SCN) (5), were characterized by X-ray structural analysis. Two type of colourless crystals (3 and 4) crystallized together from the same solution of $\left[\mathrm{Au}_{2}(\mathrm{xantphos})_{2}\right]\left(\mathrm{SbF}_{6}\right)_{2}$. The $\left[\mathrm{Au}_{2}(\mathrm{xantphos})_{2}\right]^{2+}$ cations have almost the same molecular structure with two xantphos ligands coordinated to two gold(I) centres with short aurophilic interaction of 2.803 (1), 2.825 (2), 2.817 (3) and $2.837 \AA$ (4), respectively. The $\left.\left[\mathrm{Au}_{2} \text { (xantphos }\right)_{2}\right]^{2+}$ cation is in a somewhat distorted figure-eight conformation in $\mathbf{1}-\mathbf{3}$, whereas in $\mathbf{4}$, it has and ideal figure-eight conformation with a twofold axis passing through the $\mathrm{Au} \cdots \mathrm{Au}$ bond. The molecular packing is primarily governed by $\mathrm{C}-\mathrm{H} \cdots \mathrm{F}$ hydrogen bonding interactions between the $\left[\mathrm{Au}_{2}(\mathrm{xantphos})_{2}\right]^{2+}$ cations and fluorinated $\mathrm{BF}_{4}^{-}, \mathrm{PF}_{6}^{-}$and $\mathrm{SbF}_{6}{ }^{-}$anions. In 5, the gold(I) centre is in a trigonal-planar geometry, and it is coordinated to two phosphorous atom of the xantphos ligand and one sulphur atom of the $\mathrm{SCN}^{-}$anion. Different anions cause some conformational changes and alter the molecular packing of these crystalline structures. These variations in the solid state structures alter the luminescent properties of the dinuclear and mononuclear gold(I) xantphos complexes. Dinuclear complexes 1, 2 and $\mathbf{4}$ exhibit intense yellow luminescence, while compound $\mathbf{3}$ and mononuclear 5 produces green emission when irradiated with a $365 \mathrm{~nm}$ UV lamp at room temperature.

\section{Keywords}

Aurophilicity $\cdot$ Gold $\cdot$ Solid-state photoluminescence $\cdot$ DFT calculation

\section{Introduction}

Gold(I) complexes are typically two-coordinate species that readily self-associate through aurophilic $\mathrm{Au} \cdots \mathrm{Au}$ interactions to form discrete dimeric, trimeric, etc. structures or extended polymeric chains [1-4]. Gold(I) monohalide dimers that have very short $\mathrm{Au} \cdots \mathrm{Au}$ distances are probably the ultimate examples of relativistic effects on molecular structure $[5,6]$. The aurophilic interaction that stabilizes the $\mathrm{Au}_{2} \mathrm{X}_{2}$ gold halides is especially strong with soft ligands, causing increasing stabilization toward the iodides [5, 6]. Theoretical studies have 
shown that the aurophilic interaction is the result of correlation effects that are enhanced by relativistic effects $[7,8]$. The aurophilic interactions between the closed-shell $\mathrm{Au}(\mathrm{I})$ centres are important in determining the solid state structures of many gold(I) compounds and contribute to the chemical and physical properties of these complexes [1-4, 9-13]. The distance between two interacting gold atoms in compounds showing aurophilic interactions is less than 3.6 A. Many gold complexes display luminescent properties, and in some cases the emission properties can be correlated with the presence of aurophilic interactions [11-13]. A number of stimuli-responsive luminescent gold(I) complexes have been found to exhibit emission colour change in response to external physical (thermal, mechanical, optical, electrical, etc.) and/or chemical (solvents, guests, anions, etc.) stimuli [14-20]. The solid-state luminescence, however, strongly depends on molecular structure and molecular packing modes modulated by the interplay of non-covalent interactions such as aurophilic, hydrogen bonding or $\pi^{\cdots} \pi$ interactions that are sensitive to external stimuli [14]. In these systems, the luminescence changes is usually associated with the alteration of non-covalent interactions or originate from molecular conformation changes. Recently, we reported some cationic gold(I)diphosphine $\left[\mathrm{Au}_{2}(\text { diphos })_{2}\right]^{2+}$ complexes $($ diphos $=$ diphosphine) with short intramolecular aurophilic interaction that exhibit reversible stimuli-responsive luminescence behaviour [2123]. The stimuli-responsive dinuclear $\left[\mathrm{Au}_{2}(\mathrm{xantphos})_{2}\right]\left(\mathrm{NO}_{3}\right)_{2}$ complex (xantphos $=9,9^{\prime}-$ dimethyl-4,5-bis(diphenylphosphino)-xanthene) exhibits reversible switching between crystalline and amorphous phases having distinctly different emission properties [21]. The conformational flexibility of the cationic $\left[\mathrm{Au}_{2}(\mathrm{xantphos})_{2}\right]^{2+}$ core allows different molecular conformations and packing arrangements modulated mainly by intramolecular aurophilic $\mathrm{Au} \cdots \mathrm{Au}$ and intermolecular $\pi \cdots \pi$ interactions that resulted in distinct solid state emission colours. Interestingly, owing to the conformational flexibility of the $\left[\mathrm{Au}_{2}(\mathrm{xantphos})_{2}\right]^{2+}$ cation blue, bluish green and yellow luminescent crystalline forms of the $\left[\mathrm{Au}_{2}(\mathrm{xantphos})_{2}\right]\left(\mathrm{NO}_{3}\right)_{2}$ complex have been obtained by slight modification of the crystallization conditions [21]. We have elaborated a mechanochemical method that depending on the nature of the grinding liquid provided crystalline and amorphous $\left.\left[\mathrm{Au}_{2} \text { (xantphos }\right)_{2}\right](\mathrm{X})_{2}$ complexes $\left(\mathrm{X}=\mathrm{CF}_{3} \mathrm{SO}_{3}\right.$, $\mathrm{SCN}, \mathrm{BF}_{4}$ and $\mathrm{PF}_{6}$ ) that show anion- and phase-switchable luminescent properties [22]. We also synthesized a large set of $\left[\mathrm{Au}_{2}(\text { nixantphos })_{2}\right](\mathrm{X})_{2}$ complexes (nixantphos $=4,6$ bis(diphenylphosphino)-phenoxazine; $\mathrm{X}=\mathrm{NO}_{3}, \mathrm{CF}_{3} \mathrm{COO}, \mathrm{CF}_{3} \mathrm{SO}_{3},\left[\mathrm{Au}(\mathrm{CN})_{2}\right]$ and $\mathrm{BF}_{4}$ ) that also display anion-dependent luminescence colours ranging from yellow to orange and dark red [23]. In these complexes, we combined the intramolecular aurophilic and intermolecular $\mathrm{N}-\mathrm{H} \cdots \mathrm{X}$ hydrogen bonding interactions to test their importance in determining the stimuli- 
responsive properties of these systems. We have found that the competition between these noncovalent interactions lead to unique stimuli responsive reversible thermochromic, mechanochromic and vapochromic luminescence changes [23].

Here we describe the solid state X-ray crystal structures and the luminescence behaviour of some dinuclear $\left[\mathrm{Au}_{2}(\mathrm{xantphos})_{2}\right](\mathrm{X})_{2} \quad\left(\mathrm{X}=\mathrm{BF}_{4}, \quad \mathrm{PF}_{6}\right.$ and $\left.\mathrm{SbF}_{6}\right)$ and mononuclear $\mathrm{Au}$ (xantphos)(SCN) complexes. The unique description of the symmetry is given by Magdolna Hargittai and István Hargittai in the Symmetry through the Eyes of a Chemist: "Fundamental phenomena and laws of nature are related to symmetry, and, accordingly, symmetry is one of the science's basic concepts. Perhaps it is so important in human creations because it is omnipresent in the natural world. Symmetry is beautiful although alone it may be irritating. Function, utility, and aesthetic appeal are the reasons for symmetry in technology and the arts." We will see that different weakly coordinating fluorinated $\mathrm{BF}_{4}^{-}, \mathrm{PF}_{6}^{-}$and $\mathrm{SbF}_{6}^{-}$ anions having different size and shape causes variations in the symmetry of molecular packing of $\left[\mathrm{Au}_{2}(\mathrm{xantphos})_{2}\right]^{2+}$ cations leading to the formation of various aesthetically elegant and functional 3D architectures. In addition to these dinuclear $\left[\mathrm{Au}_{2}(\mathrm{xantphos})_{2}\right](\mathrm{X})_{2}\left(\mathrm{X}=\mathrm{BF}_{4}\right.$, $\mathrm{PF}_{6}$ and $\left.\mathrm{SbF}_{6}\right)$ compounds, a mononuclear $\mathrm{Au}(\mathrm{xantphos})(\mathrm{SCN})$ complex has also been crystallized in the presence of strongly coordinating $\mathrm{SCN}^{-}$anions. Weakly coordinating anions allow the formation of $\mathrm{Au} \cdots \mathrm{Au}$ bonded dimers, while with strongly coordinating thiocyanate anion a monomeric structure was obtained. Thus, the nature of the $\mathrm{X}^{-}$anions lead to significant changes in the molecular structure, dinuclear $\left[\mathrm{Au}_{2}(\mathrm{xantphos})_{2}\right](\mathrm{X})_{2}$ versus mononuclear $\mathrm{Au}(\mathrm{xantphos})(\mathrm{X})$, as well as, in the crystal packing of these supramolecular gold(I) complexes.

\section{Experimental section}

\section{Synthesis}

The anion-exchanged gold(I) complexes have been prepared either by conventional solutionbased anion-exchange or solvent-drop assisted ball-milling technique as described earlier [22]. 


\section{Photophysical measurements}

Steady state and time-resolved luminescence measurements were carried out on an Edinburgh Instrument FLSP920 spectrofluorimeter. Spectral corrections were applied using excitation and emission correction functions of the instrument. The solid-state room temperature emission studies were conducted on finely ground powder samples placed on a Quartz Suprasil plate in a front face sample holder. Longpass filters were used to exclude the scattered excitation light.

\section{X-ray crystallography}

Crystals of 1-5 were mounted in Paratone-N oil within a conventional cryo-loop, and intensity data were collected on a Rigaku $R$-AXIS RAPID image plate diffractometer ( $\lambda(\mathrm{Ag}$ $K_{\alpha}$ radiation $)=0.56089 \AA(\mathbf{1}) ; \lambda\left(\right.$ Mo- $K_{\alpha}$ radiation $\left.)=0.71070 \AA(\mathbf{2}-\mathbf{5})\right)$, fitted with an $\mathrm{X}-$ stream low temperature attachment. Crystal data, data collection and refinement details for complexes 1-5 are listed in Table 1. Several scans in the $\varphi$ and $\omega$ direction were made to increase the number of redundant reflections, which were averaged over the refinement cycles. All calculations were carried out using the WinGX package of crystallographic programs [25]. The structures were solved by direct method (SIR92) [26] and refined by fullmatrix least-squares (SHELXL-2014/7) [27]. All non-hydrogen atoms were refined anisotropically in $F^{2}$ mode. Hydrogen atomic positions were generated from assumed geometries. The riding model was applied for the hydrogen atoms. Features of WinGX [25], PLATON [28] and Mercury [29] were used for data analysis. The structures were deposited at the Cambridge Data Centre and allocated with CCDC $1404362-1404366$ numbers. 
Table 1 Crystal data and structure refinement parameters for complexes 1-5

\begin{tabular}{|c|c|c|c|c|c|}
\hline Complex & 1 & 2 & 3 & 4 & 5 \\
\hline Formula & $\begin{array}{l}\mathrm{C}_{78} \mathrm{H}_{64} \mathrm{Au}_{2} \mathrm{O}_{2} \mathrm{P}_{4}, \\
2\left(\mathrm{BF}_{4}\right) \\
2.56\left(\mathrm{CH}_{2} \mathrm{Cl}_{2}\right)\end{array}$ & $\begin{array}{l}\mathrm{C}_{78} \mathrm{H}_{64} \mathrm{Au}_{2} \mathrm{O}_{2} \mathrm{P}_{4}, \\
2\left(\mathrm{PF}_{6}\right), \\
2.07\left(\mathrm{CH}_{2} \mathrm{Cl}_{2}\right)\end{array}$ & $\begin{array}{l}\mathrm{C}_{78} \mathrm{H}_{64} \mathrm{Au}_{2} \mathrm{O}_{2} \mathrm{P}_{4} \\
2\left(\mathrm{SbF}_{6}\right)\end{array}$ & $\begin{array}{l}\mathrm{C}_{78} \mathrm{H}_{64} \mathrm{Au}_{2} \mathrm{O}_{2} \mathrm{P}_{4}, \\
2\left(\mathrm{SbF}_{6}\right), \\
2.3\left(\mathrm{CH}_{2} \mathrm{Cl}_{2}\right)\end{array}$ & $\begin{array}{l}\mathrm{C}_{39} \mathrm{H}_{32} \mathrm{AuOP}_{2} \text {, } \\
\mathrm{SCN}, \mathrm{CH}_{2} \mathrm{Cl}_{2}\end{array}$ \\
\hline Formula weight & 1942.15 & 2017.2 & 2022.64 & 2266.30 & 918.57 \\
\hline Crystal size & $0.33 \times 0.40 \times$ & $0.28 \times 0.33 \times$ & $0.10 \times 0.15 \times$ & $0.30 \times 0.42 \times$ & $0.30 \times 0.42 \times$ \\
\hline$[\mathrm{mm}]$ & 0.47 & 0.63 & 0.50 & 0.42 & 0.42 \\
\hline Colour & colourless & colourless & colourless & colourless & colourless \\
\hline Crystal system & monoclinic & monoclinic & monoclinic & monoclinic & monoclinic \\
\hline Space group & $P 2_{1} / c$ & $P 2_{1} / c$ & $P 2_{1} / n$ & $C 2 / c$ & $P 2_{1} / c$ \\
\hline Temp. (K) & 143 & 103 & 103 & 105 & 98 \\
\hline$a[\AA]$ & $11.706(2)$ & $11.8163(3)$ & $17.4375(6)$ & $28.948(4)$ & $18.0962(3)$ \\
\hline$b[\AA]$ & $25.452(5)$ & $25.2961(7)$ & $22.6716(10)$ & $17.494(3)$ & $21.1882(5)$ \\
\hline$c[\AA]$ & $25.940(6)$ & $27.1270(8)$ & $18.4671(8)$ & $21.740(3)$ & $22.3032(4)$ \\
\hline$\alpha\left[{ }^{\circ}\right]$ & 90 & 90 & 90 & 90 & 90 \\
\hline$\beta\left[^{\circ}\right]$ & $98.755(9)$ & $98.809(1)$ & $98.499(1)$ & $131.033(13)$ & $121.152(1)$ \\
\hline$\gamma\left[{ }^{\circ}\right]$ & 90 & 90 & 90 & 90 & 90 \\
\hline$V\left[\AA^{3}\right]$ & $7639(3)$ & $8012.8(4)$ & $7220.5(5)$ & $8305(3)$ & $7318.5(3)$ \\
\hline$Z$ & 4 & 4 & 4 & 4 & 8 \\
\hline$d_{\text {calc }}\left[\mathrm{Mg} / \mathrm{m}^{3}\right]$ & 1.689 & 1.672 & 1.861 & 1.813 & 1.667 \\
\hline$\mu\left[\mathrm{mm}^{-1}\right]$ & 2.266 & 3.990 & 4.958 & 4.490 & 4.345 \\
\hline $\begin{array}{l}\text { No. of obsd. } \\
\text { reflns. I > } 2 \sigma(\mathrm{I})\end{array}$ & 8284 & 13229 & 11721 & 8461 & 16741 \\
\hline $\begin{array}{ll}\text { No. } & \text { of } \\
\text { parameters }\end{array}$ & 875 & 956 & 905 & 514 & 887 \\
\hline GOOF & 1.08 & 1.05 & 1.05 & 1.05 & 1.08 \\
\hline$R 1$ (obsd. data) & 0.0656 & 0.0406 & 0.0369 & 0.0441 & 0.0366 \\
\hline$w R 2$ (all data) & 0.1898 & 0.0989 & 0.0908 & 0.1136 & 0.0810 \\
\hline
\end{tabular}




\section{Computational procedures}

In the present study density functional theory (DFT) calculations were performed by using the Gaussian 09 program package at the M062X/6-31+G* level of theory [30]. The Los Alamos National Laboratory double zeta type basis set (LANL2DZ) have been used for the Au(I) atoms which is well suited to account for relativistic effects important in case of aurophilic interactions. We focused on the effect of anions on the electronic structure of complexes, therefore we used the M062X Minnesota functional which treats effectively the non-covalent interactions and performs well in the transition-metal chemistry [31]. We have chosen the DFT level of theory because it is less time-consuming than correlated methods, which permits an analysis of these large models. The model systems, $\left.\left[\mathrm{Au}_{2} \text { (xantphos }\right)_{2}\right](\mathrm{X})_{2}\left(\mathrm{X}=\mathrm{CF}_{3} \mathrm{SO}_{3}\right.$, $\mathrm{SCN}, \mathrm{BF}_{4}$ and $\left.\mathrm{PF}_{6}\right)$ and $\mathrm{Au}(\mathrm{xantphos})(\mathrm{SCN})$, used in the computational studies were taken from the X-ray diffraction results.

\section{Results and discussion}

The dichloromethane-assisted mechanochemical anion-exchange reaction was carried out by ball-milling $\left.\left[\mathrm{Au}_{2} \text { (xantphos) }\right)_{2}\right]\left(\mathrm{NO}_{3}\right)_{2}$ with $\mathrm{NaX}\left(\mathrm{X}=\mathrm{BF}_{4}, \mathrm{PF}_{6}, \mathrm{SbF}_{6}\right.$ and $\left.\mathrm{SCN}\right)$ salts in a 1:2 molar ratio [22]. The white powders obtained either by conventional solution-based method or mechanochemical anion-exchange reaction were redissolved in a minimum volume of dichloromethane and layered with diethylether to produce colourless solvated crystals of $\left.\left[\mathrm{Au}_{2} \text { (xantphos) }\right)_{2}\right]\left(\mathrm{BF}_{4}\right)_{2} \cdot 2.56 \mathrm{CH}_{2} \mathrm{Cl}_{2} \quad(\mathbf{1})$ and $\left.\left[\mathrm{Au}_{2} \text { (xantphos) }\right)_{2}\right]\left(\mathrm{PF}_{6}\right)_{2} \cdot 2.07 \quad \mathrm{CH}_{2} \mathrm{Cl}_{2}$ (2). Crystallization yields two type of colourless $\left[\mathrm{Au}_{2}\left(\mathrm{xantphos}_{2}\right]\left(\mathrm{SbF}_{6}\right)_{2} \quad\right.$ (3) and $\left.\left[\mathrm{Au}_{2} \text { (xantphos) }\right)_{2}\right]\left(\mathrm{SbF}_{6}\right)_{2} \cdot 2.30 \mathrm{CH}_{2} \mathrm{Cl}_{2}$ (4) crystals. Fig. $\mathrm{S} 1$ shows the photographs of these crystals under $365 \mathrm{~nm}$ UV lamp irradiation. This photograph demonstrates that green-emitting $\mathbf{3}$ and yellow-emitting $\mathbf{4}$ forms crystallize concomitantly. Balch and coworkers reported some dinuclear gold(I) complexes of bis-(diphenylphosphino)ethane (dppe) ligand, $\mathrm{Au}_{2}(\mathrm{dppe})_{2} \mathrm{X}_{2}$ $(\mathrm{X}=\mathrm{Br}$ and $\mathrm{I})$, that can crystallize concomitantly and exhibit distinct luminescence colours $[32,33]$. Single crystals of a mononuclear $\mathrm{Au}(\mathrm{xantphos})(\mathrm{SCN})$ complex (5) were obtained from dichloromethane/diethylether solution. 
Structures of the dinuclear $\left[\mathrm{Au}_{2}(\text { xantphos })_{2}\right](\mathrm{X})_{2}\left(\mathrm{X}=\mathrm{BF}_{4}, \mathrm{PF}_{6}\right.$ and $\left.\mathrm{SbF}_{6}\right)$ complexes 1-4

According to Dunitz “... crystallization itself is an impressive display of supramolecular selfassembly, involving specific molecular recognition at an amazing level of precision [34].” Complexes 1-4 crystallized in monoclinic space groups, $P 2_{1} / c$ (1 and 2), $P 2_{1} / n(\mathbf{3})$ and $C 2 / c$ (4), respectively. Crystal data of these gold(I) complexes are given in Table 1. There are disordered solvent molecules in the crystal structures of $\mathbf{1}, 2$ and 4. In 4, the $\mathrm{SbF}_{6}{ }^{-}$anions are also disordered. Selected bond distances, angles and torsion angles are presented in Table 2. As shown in Fig. 1, the cationic $\left[\mathrm{Au}_{2}(\mathrm{xantphos})_{2}\right]^{2+}$ core is in a somewhat distorted figureeight conformation in 1-3. For these 1-3 complexes, the structure of a representative $\left[\mathrm{Au}_{2}(\mathrm{xantphos})_{2}\right]^{2+}$ cation is shown in Fig. 1 . In $\mathbf{4}$, the $\left[\mathrm{Au}_{2}(\mathrm{xantphos})_{2}\right]^{2+}$ cation has ideal figure-eight conformation in which the twofold axis passes through the $\mathrm{Au} \cdots \mathrm{Au}$ bond (Fig. 2). It is particularly significant to note that the figure-eight motif is chiral since it could have a left or right disposition of the intercrossing helices $[35,36]$. As these dinuclear gold(I) complexes crystallized in centrosymmetric space groups, left-handed and right-handed forms of the $\left[\mathrm{Au}_{2}(\text { xantphos })_{2}\right]^{2+}$ cations were present in the crystal structures of 1-4. Figs. 1 and 2 illustrate different enantiomers of the same $\left.\left[\mathrm{Au}_{2} \text { (xantphos }\right)_{2}\right]^{2+}$ cation in figure eight conformation. As shown in these Figures, the gold(I) ion is coordinated to two phosphorous atoms from different bridging diphosphine ligand. The bridging xantphos ligands form nearly linear $\mathrm{P}-\mathrm{Au}-\mathrm{P}$ angles (Table 2). At the molecular level, however, the major conformational difference is reflected in the $\mathrm{P}-\mathrm{Au}-\mathrm{P}$ angle, which is about $6.4^{\circ}$ smaller in $\mathbf{1}$ than in $\mathbf{3}$. The two ligand strands are folded by ca. $78.3-85.4^{\circ}$ angles (Table 2) with respect to the $\mathrm{Au} \cdots \mathrm{Au}$ axis of the $\left[\mathrm{Au}_{2}(\mathrm{xantphos})_{2}\right]^{2+}$ cation. The intramolecular $\mathrm{Au} \cdots \mathrm{Au}$ distance ranges from 2.803(1) to 2.837(1) $\AA$ (Table 2). The $\left[\mathrm{Au}_{2}(\mathrm{xantphos})_{2}\right]^{2+}$ cation in $\mathbf{1}$ assume a compressed conformation with shorter intramolecular $\pi \cdots \pi$ interaction between the xanthene chromophores than in other complexes (centroid-centroid distance $=4.97 \AA$ in $\mathbf{1}, 5.31 \AA$ in $\mathbf{2}$ and $5.44 \AA$ in 3 ). 


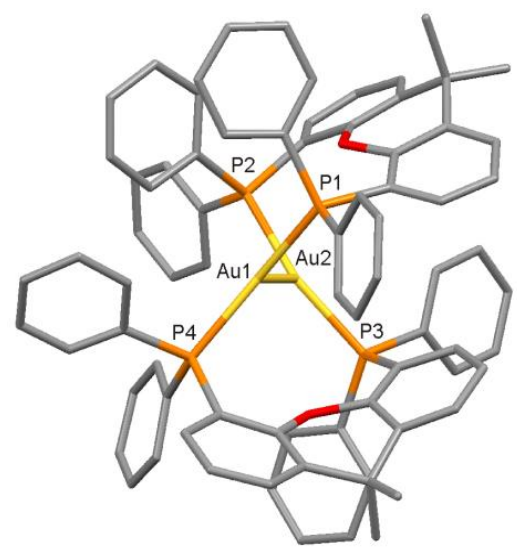

Fig. 1 Molecular structure of the $\left[\mathrm{Au}_{2}(\mathrm{xantphos})_{2}\right]^{2+}$ cation in 1-3. Colour scheme: gold, yellow; phosphorous, orange; carbon, grey; oxygen, red. The hydrogen atoms have been omitted

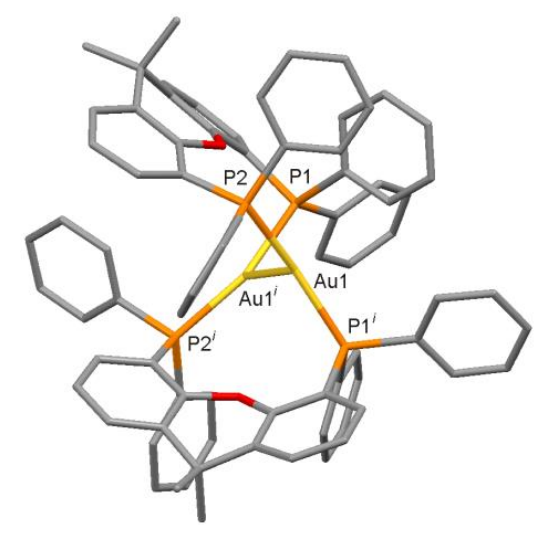

Fig. 2 Molecular structure of the $\left[\mathrm{Au}_{2}(\mathrm{xantphos})_{2}\right]^{2+}$ cation in 4. Colour scheme: gold, yellow; phosphorous, orange; carbon, grey; oxygen, red. The hydrogen atoms have been omitted 
Table 2 Selected bond lengths $(\AA)$, angles $\left(^{\circ}\right)$ and torsion angles $\left(^{\circ}\right)$ for complexes $\mathbf{1}-\mathbf{5}$, respectively

\begin{tabular}{|c|c|c|c|c|c|c|c|}
\hline & 1 & 2 & 3 & 4 & & 5 & \\
\hline $\mathrm{Au}(1) \cdots \mathrm{Au}(2)$ & $2.803(1)$ & $2.825(1)$ & $2.817(1)$ & $\mathrm{Au}(1)^{\cdots} \mathrm{Au}(1)^{i}$ & $2.837(1)$ & $\mathrm{Au}(1)-\mathrm{P}(1)$ & $2.412(1)$ \\
\hline $\mathrm{Au}(1)-\mathrm{P}(1)$ & $2.302(4)$ & $2.317(2)$ & $2.316(2)$ & $\mathrm{Au}(1)-\mathrm{P}(1)$ & $2.328(2)$ & $\mathrm{Au}(1)-\mathrm{P}(2)$ & $2.326(1)$ \\
\hline $\mathrm{Au}(2)-\mathrm{P}(3)$ & $2.311(3)$ & $2.312(2)$ & $2.312(2)$ & & & $\mathrm{Au}(2)-\mathrm{P}(3)$ & $2.323(1)$ \\
\hline \multirow[t]{2}{*}{$\mathrm{Au}(1)-\mathrm{P}(4)$} & $2.319(4)$ & $2.326(2)$ & $2.312(2)$ & & & $\mathrm{Au}(2)-\mathrm{P}(4)$ & $2.411(1)$ \\
\hline & & & & & & $\mathrm{Au}(2)-\mathrm{S}(2)$ & $2.426(1)$ \\
\hline $\mathrm{P}(2)-\mathrm{Au}(2)-\mathrm{P}(3)$ & $162.9(2)$ & $163.1(1)$ & $164.8(1)$ & & & $\mathrm{P}(3)-\mathrm{Au}(2)-\mathrm{P}(4)$ & $113.7(1)$ \\
\hline $\mathrm{P}(1)-\mathrm{Au}(1)-\mathrm{Au}(2)-\mathrm{P}(2)$ & $-79.5(1)$ & $-78.3(1)$ & $-85.4(1)$ & $\mathrm{P}(1)-\mathrm{Au}(1)-\mathrm{Au}(1)^{i}-\mathrm{P}(2)^{i}$ & $83.4(1)$ & $\mathrm{S}(1)-\mathrm{Au}(1)-\mathrm{P}(1)-\mathrm{P}(2)$ & 0 \\
\hline $\mathrm{P}(4)-\mathrm{Au}(1)-\mathrm{Au}(2)-\mathrm{P}(3)$ & $-82.8(1)$ & $-82.1(1)$ & $-81.3(1)$ & $\mathrm{P}(2)-\mathrm{Au}(1)-\mathrm{Au}(1)^{i}-\mathrm{P}(2)^{i}$ & $-86.6(1)$ & $\mathrm{S}(2)-\mathrm{Au}(2)-\mathrm{P}(3)-\mathrm{P}(4)$ & $179.4(1)$ \\
\hline $\mathrm{P}(1)-\mathrm{Au}(1)-\mathrm{Au}(2)-\mathrm{P}(3)$ & $92.1(1)$ & $93.9(1)$ & $88.2(1)$ & $\mathrm{P}(1)-\mathrm{Au}(1)-\mathrm{Au}(1)^{i}-\mathrm{P}(1)^{i}$ & $-106.6(1)$ & & \\
\hline
\end{tabular}

Operator for generating equivalent atoms: $i=-\mathrm{x}+2, \mathrm{y},-\mathrm{z}+1 / 2$

As was revealed by X-ray diffraction, the bulkiness of the xantphos ligand prevents the formation of intermolecular aurophilic $\mathrm{Au} \cdots \mathrm{Au}$ interactions in all these crystal structures. Hence the molecular packing is primarily governed by $\mathrm{C}-\mathrm{H} \cdots \mathrm{F}$ hydrogen bonding interactions between the $\left.\left[\mathrm{Au}_{2} \text { (xantphos }\right)_{2}\right]^{2+}$ cations and fluorinated $\mathrm{BF}_{4}^{-}, \mathrm{PF}_{6}^{-}$and $\mathrm{SbF}_{6}^{-}$ anions. The crystal structure of $\mathbf{1}$ is very similar to that of $\mathbf{2}$, as these complexes crystallized in a common monoclinic space group $P 2_{1} / c$. As shown in Figs. 3 and 4 , the twisted-core $\left.\left[\mathrm{Au}_{2} \text { (xantphos) }\right)_{2}\right]^{2+}$ cations and their $\mathrm{BF}_{4}^{-}$or $\mathrm{PF}_{6}^{-}$anions are connected by $\mathrm{C}-\mathrm{H} \cdots \mathrm{F}$ interactions (Tables 3 and 4) and form helices with a twofold screw axis in both crystal structures. The helices interact with neighbouring helices through $\mathrm{C}-\mathrm{H} \cdots \mathrm{F}$ interactions (Tables 3 and 4). The similarity between these crystals structures is also reflected in the magnitude of the helical pitch, which is ca. 25.4 (1) and 25.3 (2) A, respectively. 


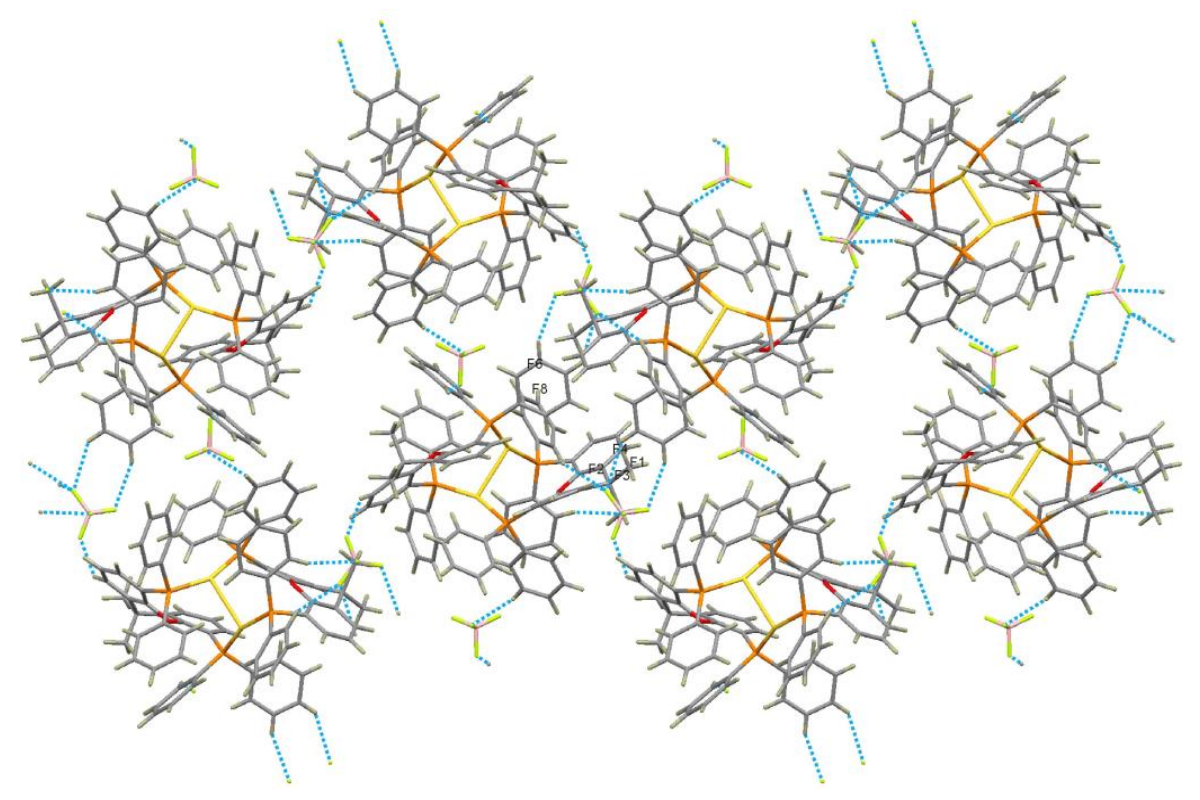

Fig. 3 View illustrating the $\mathrm{C}-\mathrm{H} \cdots \mathrm{F}$ hydrogen-bonding between $\left[\mathrm{Au}_{2}(\mathrm{xantphos})_{2}\right]^{2+}$ cations and $\mathrm{BF}_{4}{ }^{-}$counter-anions in the crystal structure of $\mathbf{1}$

Table 3 Hydrogen bond geometry $\left(\AA,^{\circ}\right)$ for $\mathbf{1}$

\begin{tabular}{lllll}
\hline $\mathrm{D}-\mathrm{H} \cdots \mathrm{A}$ & $\mathrm{D}-\mathrm{H}$ & $\mathrm{H} \cdots \mathrm{A}$ & $\mathrm{D} \cdots \mathrm{A}$ & $\mathrm{D}-\mathrm{H} \cdots \mathrm{A}$ \\
\hline $\mathrm{C}(23)-\mathrm{H}(23) \cdots \mathrm{F}(3)^{i}$ & 0.95 & 2.55 & $3.36(2)$ & 121 \\
$\mathrm{C}(2 \mathrm{C})-\mathrm{H}(2 \mathrm{C}) \cdots \mathrm{F}(2)^{i i}$ & 0.95 & 2.52 & $3.27(3)$ & 136 \\
$\mathrm{C}(6 \mathrm{D})-\mathrm{H}(6 \mathrm{D}) \cdots \mathrm{F}(4)^{i i}$ & 0.95 & 2.45 & $3.32(2)$ & 154 \\
$\mathrm{C}(4)-\mathrm{H}(4) \cdots \mathrm{F}(4)^{i i i}$ & 0.95 & 2.45 & $3.21(2)$ & 137 \\
$\mathrm{C}(2 \mathrm{~F})-\mathrm{H}(2 \mathrm{~F}) \cdots \mathrm{F}(8)^{i}$ & 0.95 & 2.44 & $3.32(2)$ & 155 \\
$\mathrm{C}(5 \mathrm{E})-\mathrm{H}(5 \mathrm{E}) \cdots \mathrm{F}(1)^{i v}$ & 0.95 & 2.41 & $3.25(2)$ & 148 \\
$\mathrm{C}(4 \mathrm{E})-\mathrm{H}(4 \mathrm{E}) \cdots \mathrm{F}(4)^{i v}$ & 0.95 & 2.51 & $3.23(2)$ & 132 \\
$\mathrm{C}(5 \mathrm{~B})-\mathrm{H}(5 \mathrm{~B}) \cdots \mathrm{F}(6)^{v}$ & 0.95 & 2.54 & $3.41(2)$ & 154 \\
\hline $\mathrm{Symmet}$ & & & &
\end{tabular}

Symmetry codes: $(i)=\mathrm{x}, \mathrm{y}, \mathrm{z} ;(i i)=-\mathrm{x},-1 / 2+\mathrm{y}, 1 / 2-\mathrm{z} ;(i i i)=1-\mathrm{x},-1 / 2+\mathrm{y}, 1 / 2-\mathrm{z} ;(i v)=\mathrm{x}$, $1 / 2-\mathrm{y}, 1 / 2+\mathrm{z} ;(v)=-1+\mathrm{x}, 1 / 2-\mathrm{y},-1 / 2+\mathrm{z}$ 


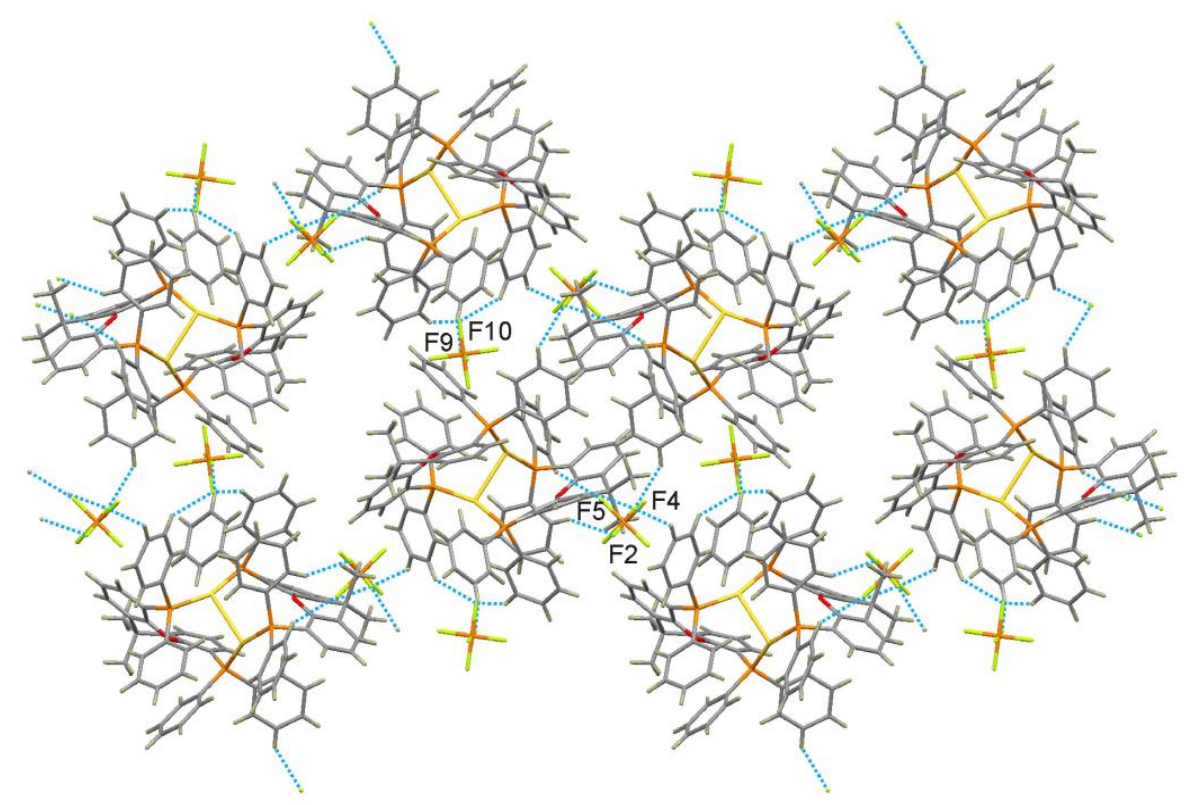

Fig. 4 View illustrating the $\mathrm{C}-\mathrm{H} \cdots \mathrm{F}$ hydrogen-bonding between $\left[\mathrm{Au}_{2}(\mathrm{xantphos})_{2}\right]^{2+}$ cations and $\mathrm{PF}_{6}{ }^{-}$counter-anions in the crystal structure of 2

Table 4 Hydrogen bond geometry $\left(\AA,^{\circ}\right)$ for 2

\begin{tabular}{lllll}
\hline $\mathrm{D}-\mathrm{H} \cdots \mathrm{A}$ & $\mathrm{D}-\mathrm{H}$ & $\mathrm{H} \cdots \mathrm{A}$ & $\mathrm{D} \cdots \mathrm{A}$ & $\mathrm{D}-\mathrm{H} \cdots \mathrm{A}$ \\
\hline $\mathrm{C}(4 \mathrm{H})-\mathrm{H}(4 \mathrm{H}) \cdots \mathrm{F}(4)^{i}$ & 0.95 & 2.40 & $3.19(1)$ & 141 \\
$\mathrm{C}(2 \mathrm{C})-\mathrm{H}(2 \mathrm{C}) \cdots \mathrm{F}(2)^{i i}$ & 0.95 & 2.45 & $3.08(1)$ & 124 \\
$\mathrm{C}(6 \mathrm{D})-\mathrm{H}(6 \mathrm{D}) \cdots \mathrm{F}(5)^{i i}$ & 0.95 & 2.48 & $3.23(1)$ & 144 \\
$\mathrm{C}(4)-\mathrm{H}(4) \cdots \mathrm{F}(4)^{i i i}$ & 0.95 & 2.43 & $3.30(1)$ & 152 \\
$\mathrm{C}(3 \mathrm{H})-$ & 0.95 & 2.47 & $3.17(2)$ & 132 \\
$\mathrm{H}(3 \mathrm{H}) \cdots \mathrm{F}(10)^{i v}$ & & & & \\
$\mathrm{C}(5 \mathrm{~B})-\mathrm{H}(5 \mathrm{~B}) \cdots \mathrm{F}(10)^{i v}$ & 0.95 & 2.53 & $3.38(1)$ & 150 \\
$\mathrm{C}(5 \mathrm{~B})-\mathrm{H}(5 \mathrm{~B}) \cdots \mathrm{F}(10)^{i v}$ & 0.95 & 2.59 & $3.17(1)$ & 120 \\
$\mathrm{C}(5 \mathrm{E})-\mathrm{H}(5 \mathrm{E}) \cdots \mathrm{F}(4)^{v}$ & 0.95 & 2.45 & $3.25(1)$ & 142 \\
$\mathrm{C}(3 \mathrm{~A})-\mathrm{H}(3 \mathrm{~A}) \cdots \mathrm{F}(9)^{v}$ & 0.95 & 2.33 & $3.12(1)$ & 140
\end{tabular}

Symmetry codes: $($ i $)=-1+\mathrm{x}, \mathrm{y}, \mathrm{z} ;($ ii $)=-\mathrm{x},-1 / 2+\mathrm{y}, 1 / 2-\mathrm{z} ; \quad$ (iii) $=1-\mathrm{x},-1 / 2+\mathrm{y}, 1 / 2-\mathrm{z} ;$ (iv) $=-1+\mathrm{x}, 1 / 2-\mathrm{y},-1 / 2+\mathrm{z} ;(v)=\mathrm{x}, 1 / 2-\mathrm{y}, 1 / 2+\mathrm{z}$ 
The concomitantly obtained 3 and $\mathbf{4}$ crystallized in different space groups, $P 2_{1} / n$ versus $C 2 / c$, having different cell dimensions. These differences result in different molecular packing arrangements and interactions between the $\left.\left[\mathrm{Au}_{2} \text { (xantphos }\right)_{2}\right]^{2+}$ cations and $\mathrm{SbF}_{6}{ }^{-}$anions in these two crystalline forms. This different molecular packing of $\left[\mathrm{Au}_{2}(\mathrm{xantphos})_{2}\right]^{2+}$ cations and $\mathrm{SbF}_{6}^{-}$anions in $\mathbf{3}$ and $\mathbf{4}$ is shown in Figs. 5 and 6 , respectively. In $\mathbf{3}$, the $\left.\left[\mathrm{Au}_{2} \text { (xantphos) }\right)_{2}\right]^{2+}$ cations and $\mathrm{SbF}_{6}^{-}$anions are associated through $\mathrm{C}-\mathrm{H} \cdots \mathrm{F}$ interactions (Table 5) and form helices with a helical pitch of ca. $22.7 \AA$. As in $\mathbf{1}$ and $\mathbf{2}$, there are additional $\mathrm{C}-\mathrm{H} \cdots \mathrm{F}$ interactions between the neighbouring helices (Table 5). As can be seen in Fig. 6, the packing arrangement in $\mathbf{4}$ is more complicated, there are two $\left[\mathrm{Au}_{2}(\mathrm{xantphos})_{2}\right]^{2+}$ cations that are linked by $\mathrm{SbF}_{6}{ }^{-}$anions through $\mathrm{C}-\mathrm{H} \cdots \mathrm{F}$ interactions (Table 6). The as-formed dimers are arranged in a "brick-wall" packing pattern, and the $\mathrm{SbF}_{6}{ }^{-}$anions interlink them through $\mathrm{C}-\mathrm{H} \cdots \mathrm{F}$ interactions (Table 6).

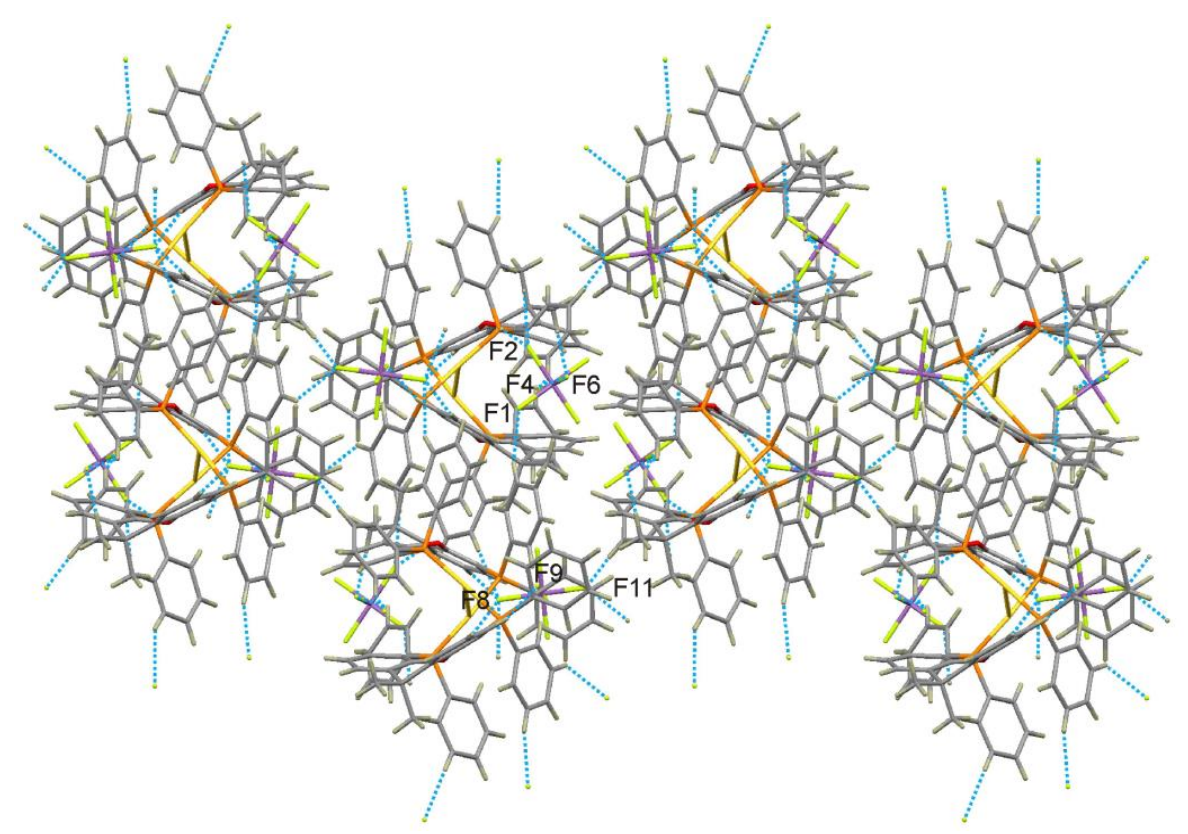

Fig. 5 View illustrating the $\mathrm{C}-\mathrm{H} \cdots \mathrm{F}$ hydrogen-bonding between $\left[\mathrm{Au}_{2}(\mathrm{xantphos})_{2}\right]^{2+}$ cations and $\mathrm{SbF}_{6}{ }^{-}$counter-anions in the crystal structure of $\mathbf{3}$ 
Table 5 Hydrogen bond geometry $\left(\AA,^{\circ}\right)$ for 3

\begin{tabular}{|c|c|c|c|c|}
\hline $\mathrm{D}-\mathrm{H} \cdots \mathrm{A}$ & $\mathrm{D}-\mathrm{H}$ & $\mathrm{H} \cdots \mathrm{A}$ & $\mathrm{D} \cdots \mathrm{A}$ & $\mathrm{D}-\mathrm{H} \cdots \mathrm{A}$ \\
\hline $\mathrm{C}(23)-\mathrm{H}(23) \cdots \mathrm{F}(2)^{i}$ & 0.95 & 2.48 & $3.35(1)$ & 151 \\
\hline $\mathrm{C}(30)-\mathrm{H}(30 \mathrm{~A}) \cdots \mathrm{F}(6)^{i}$ & 0.95 & 2.43 & $3.34(1)$ & 153 \\
\hline $\mathrm{C}(5 \mathrm{~A})-\mathrm{H}(5 \mathrm{~A}) \cdots \mathrm{F}(6)^{i}$ & 0.95 & 2.54 & $3.23(1)$ & 129 \\
\hline $\mathrm{C}(24)-\mathrm{H}(24) \cdots \mathrm{F}(8)^{i}$ & 0.95 & 2.40 & $3.30(1)$ & 159 \\
\hline $\mathrm{C}(3 \mathrm{E})-\mathrm{H}(3 \mathrm{E}) \cdots \mathrm{F}(4)^{i i}$ & 0.95 & 2.32 & $3.15(1)$ & 145 \\
\hline $\mathrm{C}(9)-\mathrm{H}(9) \cdots \mathrm{F}(8)^{i i}$ & 0.95 & 2.55 & $3.42(1)$ & 153 \\
\hline $\mathrm{C}(10)-\mathrm{H}(10) \cdots \mathrm{F}(9)^{i i}$ & 0.95 & 2.44 & $3.28(1)$ & 148 \\
\hline $\mathrm{C}(5 \mathrm{E})-\mathrm{H}(5 \mathrm{E}) \cdots \mathrm{F}(11)^{i i i}$ & 0.95 & 2.38 & $3.05(1)$ & 127 \\
\hline $\mathrm{C}(3 \mathrm{C})-\mathrm{H}(3 \mathrm{C}) \cdots \mathrm{F}(2)^{i v}$ & 0.95 & 2.33 & $3.25(1)$ & 163 \\
\hline $\mathrm{C}(3 \mathrm{~B})-\mathrm{H}(3 \mathrm{~B}) \cdots \mathrm{F}(8)^{i v}$ & 0.95 & 2.52 & $3.47(1)$ & 172 \\
\hline $\mathrm{C}(3 \mathrm{G})-\mathrm{H}(3 \mathrm{G}) \cdots \mathrm{F}(1)^{v}$ & 0.95 & 2.42 & $3.19(1)$ & 138 \\
\hline $\mathrm{C}(3 \mathrm{~F})-\mathrm{H}(3 \mathrm{~F}) \cdots \mathrm{F}(8)^{v}$ & 0.95 & 2.51 & $3.35(1)$ & 148 \\
\hline $\mathrm{C}(5 \mathrm{E})-\mathrm{H}(5 \mathrm{E}) \cdots \mathrm{F}(11)^{v i}$ & 0.95 & 2.33 & $3.12(1)$ & 141 \\
\hline
\end{tabular}

Symmetry codes: $(i)=\mathrm{x}, \mathrm{y}, \mathrm{z} ;(i i)=1+\mathrm{x}, \mathrm{y}, \mathrm{z} ;(i i i)=1-\mathrm{x},-\mathrm{y},-\mathrm{z} ;(i v)=1 / 2+\mathrm{x}, 1 / 2-\mathrm{y},-1 / 2$ $+\mathrm{z} ;(v)=1 / 2+\mathrm{x}, 1 / 2-\mathrm{y}, 1 / 2+\mathrm{z} ;(v i)=3 / 2-\mathrm{x}, 1 / 2+\mathrm{y}, 1 / 2-\mathrm{z}$

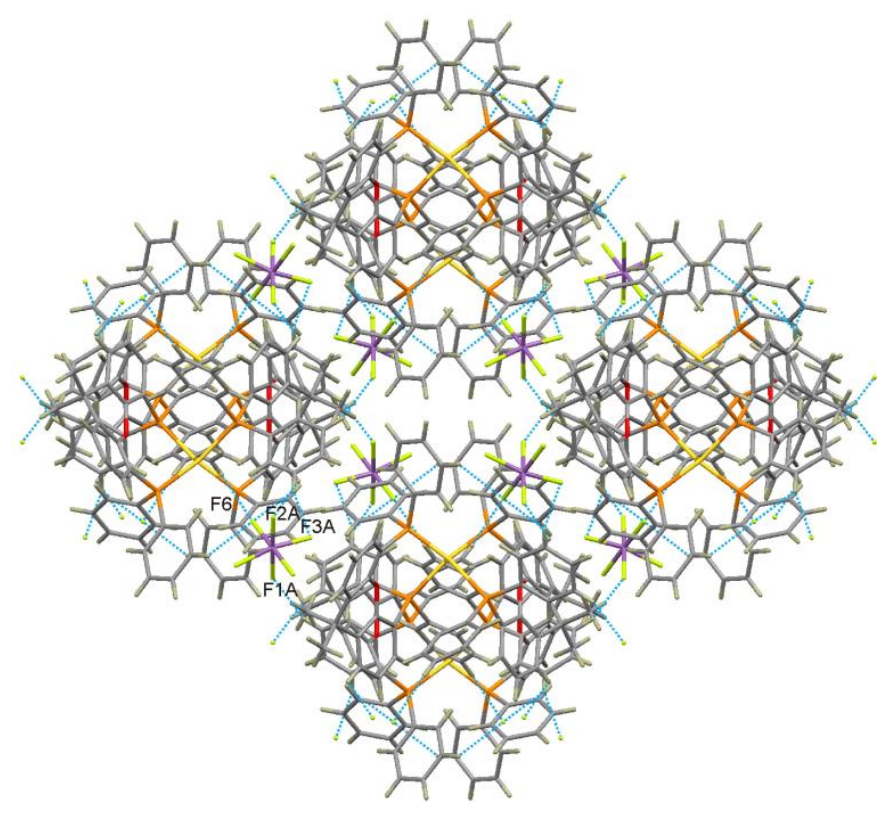

Fig. 6 View illustrating the $\mathrm{C}-\mathrm{H} \cdots \mathrm{F}$ hydrogen-bonding between $\left[\mathrm{Au}_{2}(\mathrm{xantphos})_{2}\right]^{2+}$ cations and $\mathrm{SbF}_{6}{ }^{-}$counter-anions in the crystal structure of 4 
Table 6 Hydrogen bond geometry $\left(\AA,^{\circ}\right)$ for 4

\begin{tabular}{lllll}
\hline $\mathrm{D}-\mathrm{H} \cdots \mathrm{A}$ & $\mathrm{D}-\mathrm{H}$ & $\mathrm{H} \cdots \mathrm{A}$ & $\mathrm{D} \cdots \mathrm{A}$ & $\mathrm{D}-\mathrm{H} \cdots \mathrm{A}$ \\
\hline $\mathrm{C}(5 \mathrm{D})-\mathrm{H}(5 \mathrm{D}) \cdots \mathrm{F}(1 \mathrm{~A})^{i}$ & 0.95 & 2.38 & $3.24(2)$ & 151 \\
$\mathrm{C}(3 \mathrm{D})-\mathrm{H}(3 \mathrm{D}) \cdots \mathrm{F}(3 \mathrm{~A})^{i i}$ & 0.95 & 2.52 & $3.43(2)$ & 160 \\
$\mathrm{C}(3 \mathrm{D})-\mathrm{H}(3 \mathrm{D}) \cdots \mathrm{F}(6)^{i i}$ & 0.95 & 2.38 & $3.12(2)$ & 134 \\
$\mathrm{C}(3 \mathrm{~B})-\mathrm{H}(3 \mathrm{~B}) \cdots \mathrm{F}(6)^{i i i}$ & 0.95 & 2.54 & $3.28(2)$ & 135 \\
$\mathrm{C}(8)-\mathrm{H}(8) \cdots \mathrm{F}(2 \mathrm{~A})^{i v}$ & 0.95 & 2.55 & $3.14(2)$ & 121 \\
$\mathrm{C}(4 \mathrm{C})-\mathrm{H}(4 \mathrm{C}) \cdots \mathrm{F}(6)^{v}$ & 0.95 & 2.46 & $3.28(1)$ & 144 \\
\hline
\end{tabular}

Symmetry codes: $($ i $)=\mathrm{x}, \mathrm{y}, \mathrm{z} ;(i i)==3 / 2-\mathrm{x}, 1 / 2+\mathrm{y}, 1 / 2-\mathrm{z} ;(i i i)=1 / 2+\mathrm{x}, 1 / 2+\mathrm{y}, \mathrm{z} ;(i v)=3 / 2-$ $\mathrm{x}, 1 / 2-\mathrm{y},-\mathrm{z} ;(v)=1 / 2+\mathrm{x}, 1 / 2-\mathrm{y}, 1 / 2+\mathrm{z}$

It is particularly significant to note that short intermolecular $\pi \cdots \pi$ and $\mathrm{C}-\mathrm{H} \cdots \pi$ contacts between the $\left[\mathrm{Au}_{2}(\mathrm{xantphos})_{2}\right]^{2+}$ cations are present in all these crystal structures. Moreover, in all solvated crystal structures (1, 2 and 4), the dichloromethane molecules associate through $\mathrm{C}-\mathrm{H} \cdots \mathrm{F}$ interactions with fluorinated non-coordinating $\mathrm{BF}_{4}^{-}, \mathrm{PF}_{6}^{-}$and $\mathrm{SbF}_{6}^{-}$anions. The dichloromethane molecules form $\mathrm{C}-\mathrm{H} \cdots \mathrm{S}$ interactions with the coordinated $\mathrm{SCN}^{-}$anion in $\mathbf{5}$.

\section{Structure of the mononuclear Au(xantphos)(SCN) complex 5}

Complex 5 crystallized in a monoclinic space groups, $P 2_{1} / c$. As shown in Fig. 7, there are two crystallographically independent mononuclear gold(I) complexes in the asymmetric unit of 5 . It is known that dinuclear gold(I)-diphosphine complexes can dissociate to their monomeric counterparts, and this rearrangement involves the alteration of coordination modes (bridging versus chelating) of the diphosphine ligand [37-39]. In both molecules of crystalline 5, the gold(I) centre is in trigonal-planar geometry, and it is coordinated to two phosphorous atom of the xantphos and one sulphur atom of the thiocyanate ligand (Fig. 7). The xantphos ligands are chelated to the gold(I) centres with a $\mathrm{P}-\mathrm{Au}-\mathrm{P}$ bite angle of 115.1(1) and 113.7(1) ${ }^{\circ}$, respectively. The mononuclear gold(I) complexes are associated through intermolecular $\pi \cdots \pi$ stacking interactions in the crystal structure of $\mathbf{5}$. 


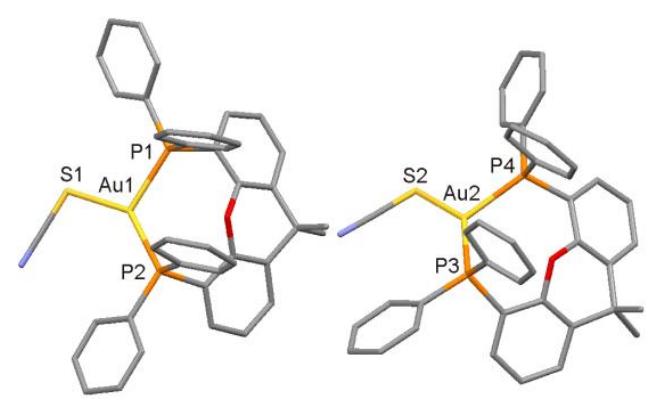

Fig. 7 Molecular structure of two crystallographically independent Au(xantphos)(SCN) molecules in the crystal structure of 5. Colour scheme: gold, yellow; phosphorous, orange; carbon, grey; oxygen, red; nitrogen, blue. The hydrogen atoms have been omitted

\section{Solid-state photoluminescence properties}

Based on crystal structures of $\mathbf{1}-\mathbf{5}$, we can conclude that these different $\mathrm{BF}_{4}^{-}, \mathrm{PF}_{6}^{-}$and $\mathrm{SbF}_{6}^{-}$ anions cause variations in the molecular packing patterns by altering the number and extent of non-covalent interactions. The intermolecular non-covalent interactions, however, can have dramatic impact on the solid-state luminescence properties of gold(I) complexes [14].

The colourless crystals of these dinuclear gold(I) complexes 1-4 display unique temperature dependent photoluminescence behaviour (Fig. 8). At room temperature, complexes 1, 2 and 4 exhibit yellow luminescence, while complex $\mathbf{3}$ produces green emission when irradiated with a $365 \mathrm{~nm}$ UV lamp. Upon freezing to $77 \mathrm{~K}$, these crystals of 1-4 show intense blue emission under $365 \mathrm{~nm}$ UV light. The thermochromic luminescence is expected to be the result of molecular structure rigidification along with thermal contraction of the crystal lattice, which also alters the extent of the noncovalent interactions [14, 23, 40]. The blue shift of the emission spectrum with decreasing temperature, however, can be explained by the presence of short aurophilic contacts, which cannot shorten more significantly upon cooling [23, 40]. Correspondence among the emission spectra of the blue emitting crystals of complexes 1-4 and glassy ethanol solution of the xantphos ligand [39] at $77 \mathrm{~K}$ indicates that luminescence occurred mainly from single molecules. Moreover, on the basis of the long emission lifetimes ( $\tau=1.3-2.5 \mathrm{~ms}$ ) of complexes 1-4, this luminescence can be attributed to the phosphorescence from the intraligand type excited state induced by the heavy atom effect of gold. At room temperature, the lifetimes and large separations between the excitation and emission bands suggests that the emission of these dinuclear crystalline solids is 
phosphorescence attributed to the aurophilic interaction modified by the non-covalent interactions existing in the crystals of $\mathbf{1}-\mathbf{4}$.

Table 7 Luminescence data for complexes $\mathbf{1 - 4}$ in the solid state at $298 \mathrm{~K}$ and $77 \mathrm{~K}$, respectively

\begin{tabular}{ccccc}
\hline Complex & \multicolumn{2}{c}{$298 \mathrm{~K}$} & \multicolumn{2}{c}{$77 \mathrm{~K}$} \\
& $\lambda_{\max }(\mathrm{nm})$ & $\tau(\mu \mathrm{s})$ & $\lambda_{\max }(\mathrm{nm})$ & $\tau(\mu \mathrm{s})$ \\
\hline $\mathbf{1}$ & 571 & 0.7 & 483 & 1340 \\
$\mathbf{2}$ & 592 & 1.4 & 469 & 1390 \\
$\mathbf{3}$ & 530 & $1.3(11 \%) 13(89 \%)$ & 480 & 2500 \\
$\mathbf{4}$ & 585 & $1.1(45 \%) 4.0(55 \%)$ & 470 & $500(22 \%) 1180$ \\
$\mathbf{5}$ & 511 & $0.4(66 \%) 4.8(34 \%)$ & 530 & $(78 \%)$ \\
\hline
\end{tabular}
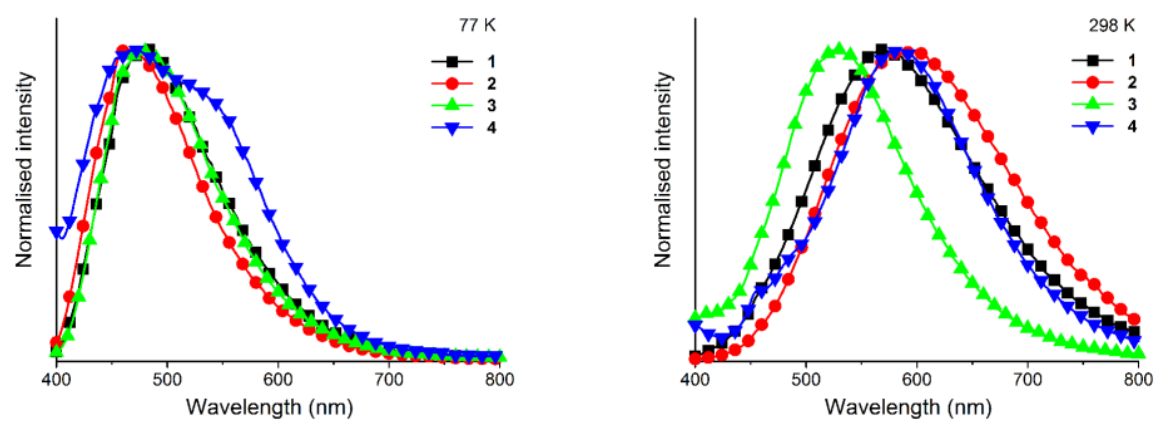

Fig. 8 Solid state emission spectra $\left(\lambda_{\mathrm{ex}}=365 \mathrm{~nm}\right)$ of complexes $\mathbf{1}-\mathbf{4}$ at room temperature (298 $\mathrm{K})$ and in liquid nitrogen $(77 \mathrm{~K})$

The mononuclear complex $\mathbf{5}$ exhibits intriguing thermochromic luminescence properties (Table 7). The colourless crystals of 5 displays bluish-green emission at room temperature (Fig. 9). At $77 \mathrm{~K}$, the emission peak of complex 5 shifts to longer wavelengths by $19 \mathrm{~nm}(8.4$ $\mathrm{kJ} \mathrm{mol}^{-1}$ ). Furthermore, the lifetime of emission at $77 \mathrm{~K}$ is substantially longer than that at 298 K. These observations suggest that luminescence from complex $\mathbf{5}$, in the solid-state at room temperature, can be tentatively ascribed to thermally activated delayed fluorescence (TADF) [41], which occurs when the $S_{1}-T_{1}$ energy gap is small enough to achieve thermal 
equilibrium between the two states. TADF has frequently been observed from $\mathrm{Cu}(\mathrm{I})$ complexes but rarely from $\mathrm{Au}(\mathrm{I})$ complexes [42].

Upon exposure to air or drying in vacuum, crystals of 1-4 lose their original emission and acquire an orange-red luminescence.

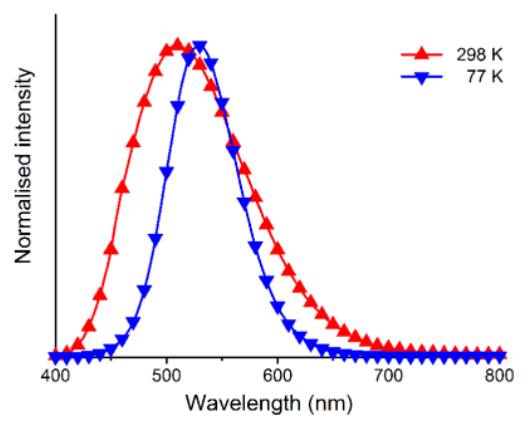

Fig. 9 Solid state emission spectra $\left(\lambda_{\mathrm{ex}}=365 \mathrm{~nm}\right)$ of complexes 5 at room temperature (298 $\mathrm{K})$ and in liquid nitrogen $(77 \mathrm{~K})$

\section{Theoretical calculations}

In order to gain a deeper insight into the influence of molecular packing on the intramolecular aurophilic interactions, we have performed quantum chemical calculations. Single point calculations were effectuated for crystalline structures of complex 1-5 fixed in their X-ray geometry, obtained in low temperature experiments. The electron-density contour plots and calculated energy levels of model systems are detailed in Fig. 10.

According to the DFT calculation results the highest occupied molecular orbital (HOMO) of complexes 1-4 is dominated by the xantphos ligand, while the lowest unoccupied molecular orbital (LUMO) of complexes $\mathbf{1 - 4}$ is located on the other xantphos ligand, gold and phosphorous atoms. The significant contribution of the $d$ orbitals of gold atoms to the LUMO points to the origin of the low-energy emission transition as being due to the intramolecular aurophilic interaction. The calculated energy gap order for $\mathbf{1}(2.63 \mathrm{eV})<\mathbf{3}(2.76 \mathrm{eV})<\mathbf{2}(2.96$ $\mathrm{eV}$ ) is in satisfying agreement with the trend of the measured emission maxima at $77 \mathrm{~K}$ (Table 7). Dinuclear complex 4 could not be included in this series, as it has different molecular packing arrangement. 


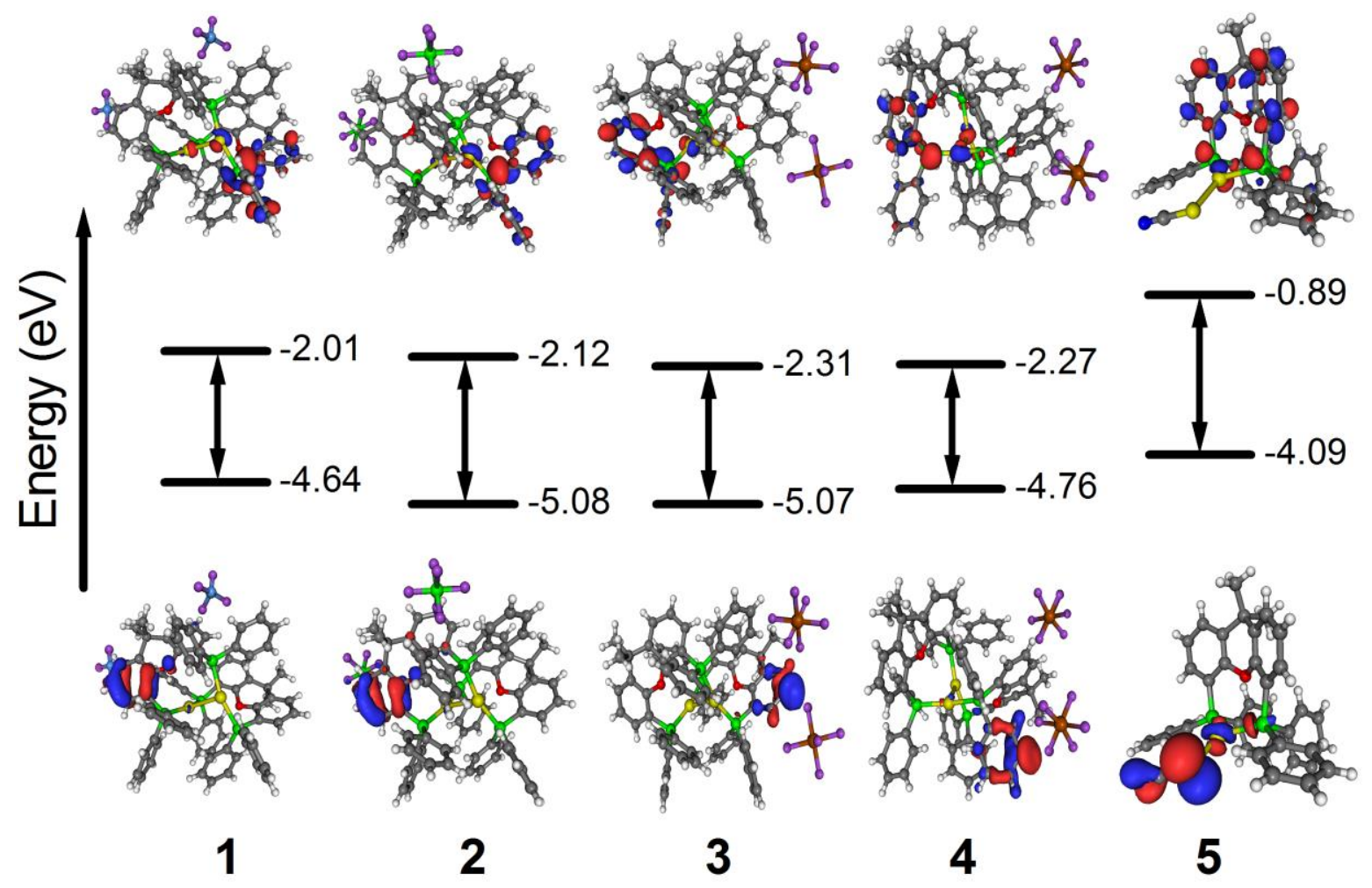

Fig. 10 The calculated shapes and energy levels of HOMO and LUMO for complexes 1-5

In order to investigate the $\mathrm{Au} \cdots \mathrm{Au}$ bond in more detail we carried out Mayer's bond order analysis [43] for the dinuclear complex 1-4 as implemented in the Gaussian 09 suite. In Table 8 , we present the calculated data. The results show that the change of the bond order indices is very limited but an inverse proportionality has been found between the $\mathrm{Au} \cdots \mathrm{Au}$ distances and the bond order indices (Fig. 11). In conclusion, the confinement of the figure-eight $\left[\mathrm{Au}_{2}(\mathrm{xantphos})_{2}\right]^{2+}$ cations in the different environment of the four crystal structures induces very slight modulation of the inner $\mathrm{Au} \cdots \mathrm{Au}$ interaction.

Table $8 \mathrm{Au} \cdots \mathrm{Au}$ bond lengths $(\AA)$ and calculated Mayer's bond order indices for complexes 1-4

\begin{tabular}{ccc}
\hline Structure & $\mathrm{Au} \cdots \mathrm{Au}$ & Bond order \\
\hline $\mathbf{1}$ & 2.803 & 0.396 \\
$\mathbf{2}$ & 2.825 & 0.378 \\
$\mathbf{3}$ & 2.817 & 0.392 \\
$\mathbf{4}$ & 2.837 & 0.360 \\
\hline
\end{tabular}




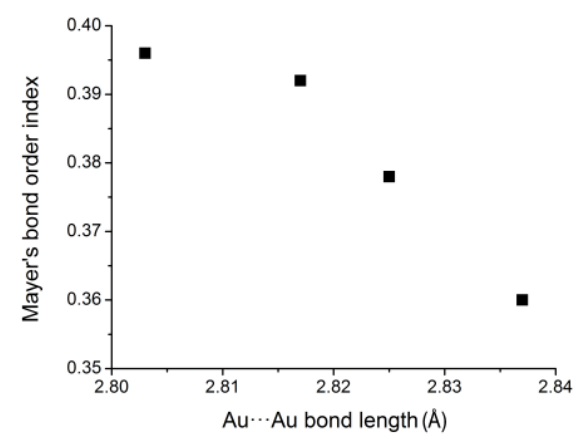

Fig. 11 Calculated Mayer's bond order index in function of $\mathrm{Au} \cdots \mathrm{Au}$ distance

In case of complex 5, the HOMO is mainly confined to gold centre and the thiocyanate ligand, and the LUMO is located primarily on the xantphos ligand and to a smaller extent on the gold centre. Thus this transition tentatively attributed to the ligand-to-ligand charge transfer (LLCT) transition with metal-to-ligand character.

\section{Conclusion}

Dinuclear $\left.\left[\mathrm{Au}_{2} \text { (xantphos) }\right)_{2}\right](\mathrm{X})_{2}$ with $\mathrm{X}=\mathrm{BF}_{4}(\mathbf{1}), \mathrm{PF}_{6}(\mathbf{2})$ and $\mathrm{SbF}_{6}(\mathbf{3}$ and 4) and mononuclear $\mathrm{Au}(\mathrm{xantphos})(\mathrm{SCN})(5)$ complexes containing the xantphos ligand (xantphos = 9,9'-dimethyl-4,5-bis(diphenylphosphino)-xanthene) were characterized by X-ray structural analysis. Two type of colourless green- (3) and yellow-emitting (4) crystals were obtained from the same dichloromethane/diethylether solution. The $\left[\mathrm{Au}_{2}(\mathrm{xantphos})_{2}\right]^{2+}$ cations have almost the same molecular structure with two xantphos ligands coordinated to two gold(I) centres with short aurophilic interaction of 2.803 (1), 2.825 (2), 2.817 (3) and $2.837 \AA$ (4), respectively. The $\left[\mathrm{Au}_{2}(\mathrm{xantphos})_{2}\right]^{2+}$ cation is in a somewhat distorted figure-eight conformation in $\mathbf{1}-\mathbf{3}$, whereas in $\mathbf{4}$, it has and ideal figure-eight conformation with a twofold axis passing through the $\mathrm{Au} \cdots \mathrm{Au}$ bond. The molecular packing is primarily governed by $\mathrm{C}-\mathrm{H} \cdots \mathrm{F}$ hydrogen bonding interactions between the $\left[\mathrm{Au}_{2}(\mathrm{xantphos})_{2}\right]^{2+}$ cations and fluorinated $\mathrm{BF}_{4}^{-}, \mathrm{PF}_{6}^{-}$and $\mathrm{SbF}_{6}^{-}$anions. In 5, the gold(I) centre is in a trigonal-planar geometry, and it is coordinated to two phosphorous atom of the xantphos ligand and one sulphur atom of the $\mathrm{SCN}^{-}$anion. Different anions cause some conformational changes and alter the molecular packing of these crystalline 1-5 structures. These variations in the solid state structures, also alter the luminescent properties of these dinuclear and mononuclear gold(I)-xantphos complexes. Dinuclear complexes exhibit intense yellow (1, 2 and 4) or green 
(3) luminescence, whereas the mononuclear gold(I) complex (5) displays green emission when irradiated with a $365 \mathrm{~nm}$ UV lamp at room temperature.

\section{Acknowledgements}

The authors gratefully acknowledge the support by MTA (Hungarian Academy of Sciences) through the Lendület Programme (LP2012-21/2012).

\section{References}

1. Laguna A (2008) Modern Supramolecular Gold Chemistry. Wiley-VCH, Weinheim, Germany

2. Gimeno MC, Laguna A (1997) Chem Rev 3:511

3. Schmidbaur H, Schier A (2008) Chem Soc Rev 37:1931

4. Schmidbaur H, Schier A (2012) Chem Soc Rev 41:370

5. Hargittai M (2009) Acc Chem Res 42:453

6. Schulz A, Hargittai M (2001) Chem Eur J 17:3657

7. Pyykkö P, Runeberg N, Mendizabal F (1997) Chem Eur J 3:1451

8. Pyykkö P, Runeberg N, Mendizabal F (1997) Chem Eur J 3:1458

9. Schmidbaur H, Graf W, Müller G (1988) Angew Chem Int Ed Engl 27:417

10. Balch AL, Fung EY, Olmstead MM (1999) J Am Chem Soc 112:5181

11. White-Morris RL, Olmstead MM, Jiang F, Tinti DS, Balch AL (2002) J Am Chem Soc $124: 2327$.

12. Malwitz MA, Lim SH, White-Morris RL, Pham DM, Olmstead MM, Balch AL (2012) J Am Chem Soc 134:10885.

13. Jiang, XF, Hau FKW, Sun QF, Yu SY, Yam VWW (2014) J Am Chem Soc 136:10921.

14. Jobbágy Cs, Deák A (2014) Eur J Inorg Chem 4434

15. Balch AL (2009) Angew Chem Int Ed 48:2641

16. Gussenhoven EM, Fettinger JC, Pham DM, Malwitz MM, Balch AL (2005) J Am Chem Soc $127: 10838$

17. Ito H, Saito T, Oshima N, Kitamura N, Ishizaka S, Hinatsu Y, Wakeshima M, Kato M, Tsuge K, Sawamura M (2008) J Am Chem Soc 130:10044

18. Osawa M, Kawata I, Igawa S, Hoshino M, Fukunaga T, Hashizume D (2010) Chem Eur J $16: 12114$ 
19. Ito H, Muromoto M, Kurenuma S, Ishizaka S, Kitamura N, Sato H, Seki T (2013) Nat Commun 4:2009

20. Seki T, Sakurada K, Ito H (2013) Angew Chem Int Ed 52:12828

21. Jobbágy Cs, Molnár M, Baranyai P, Hamza A, Pálinkás G, Deák A (2014) CrystEngComm 16:3192

22. Jobbágy Cs, Molnár M, Baranyai P, Deák A (2014) Dalton Trans 43:11807

23. Deák A, Jobbágy Cs, Marsi G, Molnár M, Szakács Z, Baranyai P (2015) Chem Eur J 21: 11495

24. Hargittai M, Hargittai I (2009) Symmetry through the eyes of a chemist. 3rd edition. Springer Science + Business Media B.V. p. 1.

25. Farrugia LJ (2012) J Appl Cryst 45:849

26. Altomare A, Cascarano G, Giacovazzo C, Guagliardi A, Burla MC, Polidori G, Camalli MJ (1994) Appl Cryst 27:435

27. Sheldrick GM (2014) SHELXL, Version 2014/7, Program for Crystal Structure Refinement, University of Göttingen

28. Spek AL (2009) Acta Cryst D65:148

29. Macrae CF, Edgington PR, McCabe P, Pidcock E, Shields GP, Taylor R, Towler M, van de Streek J (2006) J Appl Cryst 39:453

30. Gaussian 09, Revision C.01, Frisch MJ, Trucks GW, Schlegel HB, Scuseria GE, Robb MA, Cheeseman JR, Scalmani G, Barone V, Mennucci B, Petersson GA, Nakatsuji H, Caricato M, Li X, Hratchian HP, Izmaylov AF, Bloino J, Zheng G, Sonnenberg JL, Hada M, Ehara M, Toyota K, Fukuda R, Hasegawa J, Ishida M, Nakajima T, Honda Y, Kitao O, Nakai H, Vreven T, Montgomery JA, Peralta JE, Ogliaro F, Bearpark M, Heyd JJ, Brothers E, Kudin KN, Staroverov VN, Kobayashi R, Normand J, Raghavachari K, Rendell A, Burant JC, Iyengar SS, Tomasi J, Cossi M, Rega N, Millam JM, Klene M, Knox JE, Cross JB, Bakken V, Adamo C, Jaramillo J, Gomperts R, Stratmann RE, Yazyev O, Austin AJ, Cammi R, Pomelli C, Ochterski JW, Martin RL, Morokuma K, Zakrzewski VG, Voth GA, Salvador P, Dannenberg JJ, Dapprich S, Daniels AD, Farkas Ö, Foresman JB, Ortiz JV, Cioslowski J, Fox DJ, Gaussian, Inc., Wallingford CT, 2009.

31. Zhao Y, Truhlar DG (2008) Acc Chem Res 41:157

32. Lim SH, Olmstead MM, Balch AL (2011) J Am Chem Soc 133:10229

33. Lim SH, Olmstead MM, Balch AL (2013) Chem Sci 4:311

34. Dunitz JD, in Host-guest molecular interactions: from chemistry to biology, Eds.: Chadwick DJ, Widdows K (1991) John Wiley \& Sons, Chichester, p. 92. 
35. Karle IL, Ranganathan D, Haridas V (1996) J Am Chem Soc 118:10916

36. Werner A, Michels M, Zander L, Lex J, Vogel E (1999) Angew Chem Int Ed 38:3650

37. Tunyogi T, Deák A, Tárkányi G, Király P, Pálinkás G (2008) Inorg Chem 47:2049

38. Pintado-Alba A, de la Riva H, Nieuwhuyzen M, Bautista D, Raithby PR, Sparkes HA, Teat SJ, López-de-Luzuriaga JM, Lagunas MC (2004) Dalton Trans 3459

39. Deák A, Megyes T, Tárkányi G, Király P, Biczók L, Pálinkás G, Stang PJ (2006) J Am Chem Soc 128:12668

40. Fernández EJ, Laguna A, López-de-Lazuriaga JM, Monge M, Montiel M, Olmos ME, Rodríguez-Castillo M (2009) Dalton Trans 7509

41. Bergmann L, Friedrichs J, Mydlak M, Baumann T, Nieger, M, Bräse S (2013) Chem Commun 49:6501

42. Osawa M, Kawata I, Ishii R, Igawa S, Hashimoto M, Hoshino M (2013) J Mater Chem C $1: 4375$

43. Mayer I (1983) Chem Phys Lett 97:270 